of chemical carcinogens below which there will be no response in man, ${ }^{1}$ the absence of papilloma and carcinoma in the stained fingers of man to date is surely significant.

The naive histological demonstration of Dr. F. J. C. Roe and Mr. A. L. Levene (2 September, p. 615) does not have adequate relevance either. Had they demonstrated unchanged epidermal thickness in the stained fingers of heavy cigarette smokers (20 and more per day for 20 years and more) and non-smokers of comparable age, sex, and occupation in addition, they would have a leg to stand on. Nor did I ask if tobacco smoke is a carcinogen for man either. What I asked was (5 August, p. 373) whether the absence of " cigarette-smoker's finger," and the fact that not all heavy cigarette smokers develop lung cancer, did not argue for some other essential factor, in addition to cigarette smoke, for the evolution of malignant disease in any particular heavy cigarette smoker. To date I have had no answer.-I am, etc.,

Medical Centre,
Cape Town,
Republic of South Africa.
RefrerencB
$\begin{aligned} & \text { Smoking and Health, Report of the Advisory } \\ & \text { Committee to the Surgeon General of the Public }\end{aligned}$
Health Service, Publication No. 1103, 1964,

Health Service, Publication No. 1103, 1964. p. 143. Washington.

\section{Dose of Phenoperidine}

SIR,-My attention has been called to a typographical error in the recently published tenth edition of Recent Advances in Anaesthesia, published by J. \& A. Churchill Ltd., London.

On page 48 , line three the dose of phenoperidine is given as $0.5 \mathrm{mg} . / \mathrm{kg}$. instead of $0.05 \mathrm{mg} . / \mathrm{kg}$. The publishers have already arranged for an erratum slip to be pasted into this page, but some copies had previously been put into circulation. I would be grateful if you would kindly print this letter so that readers of the book can make the necessary alteration if it has not already been done, and thus avoid any risk of possible overdosage.-I am, etc.,

$$
\text { London N.6. }
$$

C. LANGTON Hewer.

\section{Crime and Sex Chromosome Anomalies}

SIR,-Recent studies ${ }^{12}$ have shown a relatively high incidence of chromosome anomalies among mentally disordered patients, a large proportion of whom were mentally subnormal, requiring treatment under special security owing to dangerous violent or criminal propensities. It has been suggested that an association exists between the possession of an extra $Y$ chromosome, increased stature, and a tendency to criminal behaviour.

We are therefore undertaking a chromosomal survey among prisoners received into H.M. Prison, Wandsworth. The two groups being examined are (a) consenting accessible prisoners of height $6 \mathrm{ft}$. (1.8 m.) or over and $(b)$ consenting accessible randomly selected prisoners admitted during the same period.

Leucocytes were cultured from peripheral blood employing the method of Moorhead et al. Results so far obtained are as follows: (a) of 34 subjects examined 31 were normal, 2 were 47 $\mathrm{XYY}$, and $147 \mathrm{XXY} ;(b)$ of 33 subjects 32 were normal and one a possible balanced translocation with 45 chromosomes (16/21-22 ?). In group (a) there were two subjects with very long $\mathrm{Y}$ chromosomes (defined as twice the length of the $G$ group chromosomes). One of these was an XYY subject.

The numbers concerned are too small to allow statistical analysis, but enlargement of the present samples may enable us to examine a number of variables connected with sex chromosome anomalies.

J. Z. has been the recipient of a grant from the Mental Health Research Fund.

-We are, etc.

\section{H.M. Prison, Wandeworth}

A. W. GRIfFiths.

London S.W.18.

St. Lawrence's Hospital,
Caterham, Surrey.

\section{J. ZAREMBA.}

\section{REFERENCBS}

' Jacobs, P. A., Brunton, M., Melville, M. M. M.,
Brittain, R. P., and McClemont, W. Brittain, R. P., and McClemont, W. F., 2 Casey, M. D., Blank, C. S., Street, D. B. M asey, M. D., Blank, C. S., Street, D. B. M.,
Segall, L. J., McDougall, J. M., McGrath, P.
J., and Skinner A. L., Lancet, 1966, 2, 859. J., and Skinner A. A., Lancet, 1966, 2, 859.
Moorhead, P. S., Nowell, P. S. N Sellman, w. J.; cell Res., 1960, 20, 613 .

\section{Major Accident Procedure}

SIR,-Many of us will recall the tragedy of the 1957 Lewisham train crash, and the haphazard manner in which the various accident services operated. As a direct result of experience gained at that time, major accident procedures were developed covering the whole country. Recently we have experienced another train crash near by, at Hither Green, but on this occasion the accident services worked well, being highly organized in their operations.

As a consequence, the planners of major accident procedures are no doubt resting content, presuming that such efficiency would have pertained elsewhere. However, in my opinion the sole reason why efficiency prevailed the other week at Hither Green was due to the fact that the same teams of personnel were involved as in 1957, having resolved that they personally would never again provide an inefficient major accident service.

Outside the Lewisham area the plans for major accidents are undoubtedly highly organized, but I for one am sceptical that these are anything but paper plans. Having worked as a casualty officer in six hospitals in the North-east Metropolitan Region in the past few years, at only one have I been made aware of the existence of the major accident procedure. As one who is deeply interested in the provision of accident services, I hope that all concerned will review their plans following the Hither Green tragedy, and make certain that the personnel involved are kept fully informed.-I am, etc.,

$$
\text { London E.15. Christopher Bolt. }
$$

\section{Computers in Medicine}

SIR,-Do you think that our profession has seen what is in this Pandora's box (4 November, p. 250) ? The lid is open and cannot be closed-but shall we be servants or masters of its contents?
Every technical advance of our era has, through our own folly, brought more harm than benefit. Need one give instances? The telephone has destroyed the privacy of thousands; the internal combustion engine the civilization of our cities; the television the freedom and orginality of our minds ; pharmaceutical advance has given us the practical certainty of world starvation; and nuclear fission the high probability of the destruction of life itself. It is a solemn warning we are generally afraid to heed.

There are ominous signs that the computer is already becoming an instrument of depersonalization and intimidation. It could be a source of new knowledge and power for the good of our strange race, but we shall have to rule it with a determination commensurate with its potentialities.-I am, etc.,

Exmouth, Devon. RichaRd HaRdy.

\section{Doctors for Industry}

SIR,-I would like to follow the lead given by Drs. G. A. Lawrenson and M. E. M. Herford (7 October, p. 52) in commenting on the leading article "Doctors for Industry" (16 September, p. 692).

As a doctor in medical charge of an Army training regiment over the past five and a half years, I have seen approximately 5,000 young men of 17 to 18 years of age coming into the Army after upwards of two years spent in mostly industrial occupations, and have carried out several brief examinations on the majority of them, which have been of great value in supervising their physical well-being and assessing their physique and state of nutrition. ${ }^{1}$ All these have been young men without specific handicaps, and, as Dr. Herford comments, would be abandoned by the Factory Medical Inspectorate of the future as needing no medical care other than the treatment of illness, in spite of much poor but partly remediable physique on the one hand, and considerable obesity on the other.

I join him in challenging this proposed change, and am in agreement with his general conception of planning the medical care of the "whole man" during the vital youthful years in industry. In the Army we have to devote considerable attention to physical requirements in order to bring our recruits up to our own modest standards of physical efficiency and nutritional well-being, and, for the most part, among those who make the grade and stay with us, we succeed very well. In consequence, lack of stamina and many other accompaniments of poor physique are remedied, as well as obesity reduced, and in addition we see little of the problems of abnormal behaviour and aggressiveness which are characteristic of this age group today. Our regimen does seem to possess something helpful for growth into maturity which is lacking in much of what society today offers young people. We do in fact provide that "whole man" care which Dr. Herford advocates.

Judging from this experience it seems to me that a medical service to young people in industry must include among other things provision for a number of routine medical examinations designed to assess growth, physique, and nutrition, so that appropriate advice or treatment may be given. In putting forward this proposal I do not intend in the least to belittle other aspects of health which 
Dr. Herford has in mind, ${ }^{2}$ upon which I cannot comment because I see little of them in my own work. Supplementing these examinations there should be facilities for remedial exercises, where indicated, and for proper midday feeding for all in this age group. In order to test out such ideas, would it not be possible to run some pilot schemes in which the results in all-round well-being after two years could be compared with those of areas where matters are allowed to proceed as at present ?-I am, etc.,

Yeovil,

R. Y. TAYLOR.

Somerset.

REFBRBNCES

Taylor, R. Y., Publ. Hlth (Lond.), 1966, 80, 146 2 Herford, M. E. M., ibid., 1962, 76, 283.

\section{Consultant Distinction Awards}

SIR,-Dr. T. Manners (4 November, p. p. 298) highlights one of the greatest problems facing the hospital service today. The tendency of the present Review Body to extend the scope of the distinction award system inevitably means that it is regarded as part of the consultant's essential salary structure. This also means that the very substantial number of consultants who will never receive an award, many of whom have little or no private practice today, will, unless some considerable changes are made, remain with few exceptions the lowest paid of all senior doctors both in the hospital service and in general practice.

This state of affairs creates two fundamental problems. It ensures that the consultant who works hard to provide the best possible National Health service to his patjents goes unrewarded, whereas his colleague who works less hard inevitably develops waiting-lists, and so patients, in desperation, begin to come to him privately. This in turn leads to less time being available for hospital work and more work falling on the shoulders of junior staff. Thus does the reward increase as the contribution to the National Health Service decreases. The second great problem concerns the integration of general practitioners into the hospital service. As one who for years has supported this policy in the form of clinical assistantships and the smaller cottage-type hospital I was delighted to see that the Scottish Working Party ${ }^{1}$ advocates its extension. They foresee that the disparity between the rewards of general practice and the basic salaries of the hospital service will prevent many general practitioners from taking on hospital commitments. On the other hand, if the medical assistant salary is increased to the point where it competes with general practice, not only the registrar but also the consultant will find that his session earns him less than his assistant.

The distinction awards can never overcome these fundamental problems, and unless the Government and Review Body realize their importance and put forward definite proposals for surmounting them the next 15 years may be remembered as a period of rising waiting-lists and a constant move towards private practice, to the lasting detriment of a hospital service the great achievement of which has been to provide for the less fortunate members of our society a standard of medical care unequalled throughout the world. No Government, and least of all a
Socialist Government, should allow anything to imperil it.-I am, etc.,

$$
\begin{aligned}
& \text { Princess Margaret Hospital, K. D. CROW. } \\
& \text { Swindon, Wilts. }
\end{aligned}
$$

\section{REPERENCB}

Organization of the Medical Work in the Hospital Service in Scotland, 1967, H.M.S.O.

\section{Countersigning of Forms}

SIR,-After a long and distressing illness a patient of mine died last month of carcinoma of the bronchus. The appropriate form for a night visit (E.C. 81a) was sent to me by the Southern Relief Service, having been signed by their doctor but not by the patient's widow. I cannot bring myself to debase my profession by taking this form round to the house of my deceased patient at the time of his widow's grief. For this reason I am sending the form to the executive council in its present state.

I feel the larger issue of having similar forms countersigned at all is a source of deep concern and dissatisfaction to all members of the medical profession.-I am, etc.,

$$
\begin{array}{ll}
\text { Wallington, } & \text { C. R. NUNAN. }
\end{array}
$$

\section{Approval of Emergency Treatment Service}

SIR,-Your correspondent Dr. A. Dowling (25 November, p. 490) attempts to defend the Emergency Treatment Service and suggests medico-political influences as the reason for its "non-starter" status in London.

I would like to question whether there is any real need of the service at all in a wellorganized general-practitioner service. Surely in most towns (at least of the size where E.T.S. operates) it should be possible for doctors to organize themselves in efficient practices with four to five partners and thus ensure about one night on in four. Is that asking too much ? And also are doctors really happy about State Registered Nurses answering the phone?

There is a lot of emotional talk about whole patient care and responsibility for one's patients, but if one of a group of general practitioners cannot be on call to deal with one of their patient's acute appendicitis, cardiac asthma, or simply answer a pertinent question are those doctors really providing a service in keeping with the tradition of good family doctoring? The answer is "no," and as soon as doctors do something about making their services efficient the sooner will schemes such as E.T.S. wither and patients will be much more satisfied.-I am, etc.,

London S.W.17.

\section{Peter Fitt.}

\section{Educating the Public}

SIR,-The Government, we are informed," has agreed to continue with the "education of the sublic in the use of doctors' services," for which we must be grateful. However, I am sure that this has been used as an argument between our negotiators and the Ministry.
Surely, if they really wished to improve the lot of individual doctors, it would be much more efficient if they set aside a proportion of the sum they are now making available for leaflets, posters, and newsflashes for a grant to individual practitioners, who could then compose their own " notes for the guidance of patients," which, if approved, could be included with the medical card sent out by the executive councils. This is a practice which has been carried out for many years by our own very helpful council and caters for the vast variety between different practices.-I am, etc.,

Cambridge.

GORDON SIMPSON.

REFERENCE

Ministry of Health Letter, E.C.L. 90/67.

\section{Simplifying Filing}

SiR,-The world is getting rather full of paper and other records, such as radiographs. Especially in medical establishments there would seem to be a lack of system with regard to what to keep and what to throw away. As far as my experience reaches there is in practice a rather arbitrary custom of deciding that after $x$ years documents must be discarded to make room for more recent ones. At this stage it is impracticable to sort them out as to their relative values, so they all go out together.

The following is a suggestion to allow documents to be marked when they are being dealt with in the first place in such a way that a clerk can go through them periodically and throw out those which have been marked with the relative lack of priority. As far as medical documents are concerned they seem to me to have four more or less separate values: Clinical " $C$ "; Research " $R$ "; Administrative "A"; and Litigious "L." The periods I suggest as being useful and not too numerous are $1,3,10,30$, and 100 years, combining these in a diagram or table:

\begin{tabular}{l|l|l|l|l|l|l}
\hline & Yrs & 1 & 3 & 10 & 30 & 100 \\
\hline & $\mathrm{C}$ & & & & & \\
\hline $\mathrm{R}$ & & & & & \\
\hline $\mathrm{U}$ & $\mathrm{A}$ & & & & & \\
\hline $\mathrm{L}$ & & & & & \\
\hline & & & & & \\
\hline
\end{tabular}

If this diagram is stamped on relevant documents it is easy when reporting on or filing the document to tick the relevant "boxes" to indicate conspicuously that a valuable report or radiograph should not be thrown away before a less valuable one. Presumably the " $C$ " and " $R$ " lines would be the responsibility of the consultant and the " $A$ " and " $L$ " lines would be the responsihility of the hospital secretary. And the whole would give a clear indication for discarding, retaining, or reassessing.

At this stage I will not enter into a lengthy discussion; that will be more fitting when the C.R.A.L. has heen tried out in practice. This is merely a preliminary notice.-I am, etc.,

Halstead, Essex. W. A. L. COLLIRR. 